УДК 556.114:553.411(571.56)

\title{
ГЕОХИМИЧЕСКИЕ ОСОБЕННОСТИ ПРИРОДНЫХ ВОД ТЕРРИТОРИИ ЗОЛОТОРУДНОГО МЕСТОРОЖДЕНИЯ ВЬЮН (РЕСПУБЛИКА САХА-(ЯКУТИЯ))
}

\author{
Язиков Егор Григорьевич 1 , \\ yazikoveg@tpu.ru
}

\author{
Мишанькин Андрей Юрьевич1, \\ aym13@tpu.ru
}

\section{Осипова Нина Александровна 1 , osipova@tpu.ru}

\author{
Филимоненко Екатерина Анатольевна ${ }^{1}$, \\ filimonenkoea@mail.ru
}

Карпенко Юрий Андреевич',

Собянин Юрий Петрович², yuri_sob63@mail.ru

1 Национальный исследовательский Томский политехнический университет, Россия, 634050, г. Томск, пр. Ленина, 30.
2000 «Богуславец», Россия, 677027, г. Якутск, ул. Кирова, 18.

\begin{abstract}
Актуальность исследования обусловлена необходимостью получения данных о состоянии природных поверхностных вод территорий золоторудных объектов, расположенных в области криолитозоны субарктического пояса.

Цель: выявление геохимических особенностей природных вод территории золоторудного месторождения Вьюн на предэксплуатационной стадии его освоения.

объект: поверхностные воды территории золоторудного месторождения Вьюн.

Фактические материалы и методы исследования. Фактический материал получен в результате выполнения научноисследовательских работ, которые проводились в 2017 г. сотрудниками кафредры геоэкологии и геохимии Национального исследовательского Томского политехнического университета. В данной работе обсуждаются результаты исследований территории золоторудного месторождения Вьюн по данным изучения водотоков, из которых было отобрано 13 проб воды. Пробы отбирались и обрабатьвались по стандартным методикам в соответствии с нормативными документами. Элементный состав воды устанавливался методом масс-спектрометрии с индуктивно связанной плазмой на содержание 71 химического элемента в аккредитованной Проблемной научно-исследовательской лаборатории гидрогеохимии научнообразовательного центра «Вода» Национального исследовательского Томского политехнического университета. Для установления гидрохимических характеристик вод образцы были проанализированы комплексом методов: титриметрическим; потенциометрическим; кондуктометрическим; гравиметрическим; фоотоколориметрическим; спектрофотометрическим; методом ионной хроматографии, а также с помощью расчетных методик в НОЦ «Вода». Результаты обрабатывались 8 программах Microsoft Excel u Statistica. Схемы и диаграммы строились при помощи графического редактора Corel Draw.

Результаты. Выявлены геохимические особенности природных вод водотоков золоторудного месторождения Вьюн в условиях вечной мерзлоты. Установлено наличие контрастных аномалий химических элементов, представленных мьшьяком и ртутью. Данные элементы являются спутниками малосульфидного золотокварцевого оруденения.
\end{abstract}

\section{Ключевые слова:}

Золоторудное месторождение Вьюн, поверхностные воды, гидрогеохимические показатели, элементный состав, геохимические особенности.

\section{Введение}

Изучению геохимии природных вод рудных месторождений посвящено большое количество работ, в которых зачастую уделяется внимание вопросам формирования состава вод под воздействием различных характеристик природных условий и геологической среды: Ю.Ф. Погребняк [1, 2], В.Н. Макаров [3], А.М. Плюснин [4], Е.М. Дутова [5]. Есть работы, посвященные особенностям водной миграции и концентрированию рудогенных элементов под влиянием различных условий, а также выделяются физико- химические исследования, касающиеся влияния параметров геохимической среды на миграционные процессы [6].

Проблемой формирования геохимических полей в районах распространения многолетнемёрзлых пород занимались И.П. Винокуров, А.М. Иванова, Н.П. Чибисов, С.Л. Шварцев начиная с 60-х гг. прошлого века. Первым исследователем, обосновавшим необходимость учёта криогенных процессов при изучении условий формирования месторождений полезных ископаемых в криолитозоне, был известный мерзлото- 
вед, член-корр. АН СССР П.Ф. Швецов [7]. Отдельное внимание исследователей уделялось объектам золотодобычи $[8,9]$.

Перспективы расширения ресурсной базы золота в России в последнее время связываются с Яно-Колымской провинцией (Восточная часть Республики Саха-Якутия и Северо-Запад Магаданской области) [10-12].

Интересным с точки зрения оценки ресурсов золота является золоторудное месторождение Вьюн (Республика Саха-(Якутия)), открытое в 1974 г. [13]. Данный объект локализован в Эльгенджинском руднороссыпном узле Адыча-Тарынской золотоносной 30ны и в более широком смысле относится к ЯноКолымской провинции. В 2017 г. были начаты поисково-оценочные работы на новых перспективных участках месторождения, что и послужило проведению комплексных эколого-геохимических исследова- ний для оценки фоновых концентраций элементов в природных компонентах окружающей среды на данных территориях.

Данная работа направлена на изучение гидрогеохимических показателей и установление фоновых концентраций химических элементов в природных водах территории золоторудного месторождения Вьюн на доэксплуатационной стадии работ в условиях вечной мерзлоты.

\section{Характеристика исследуемой территории}

Золоторудное месторождение Вьюн расположено в Азиатской части России (рис. $1, a$ ), на территории Верхоянского района Республики Саха (Якутия), в 550 км к северо-востоку от административного центра Республики - г. Якутска (рис. $1,6,6$ ), в центральной части одноименного рудного поля.

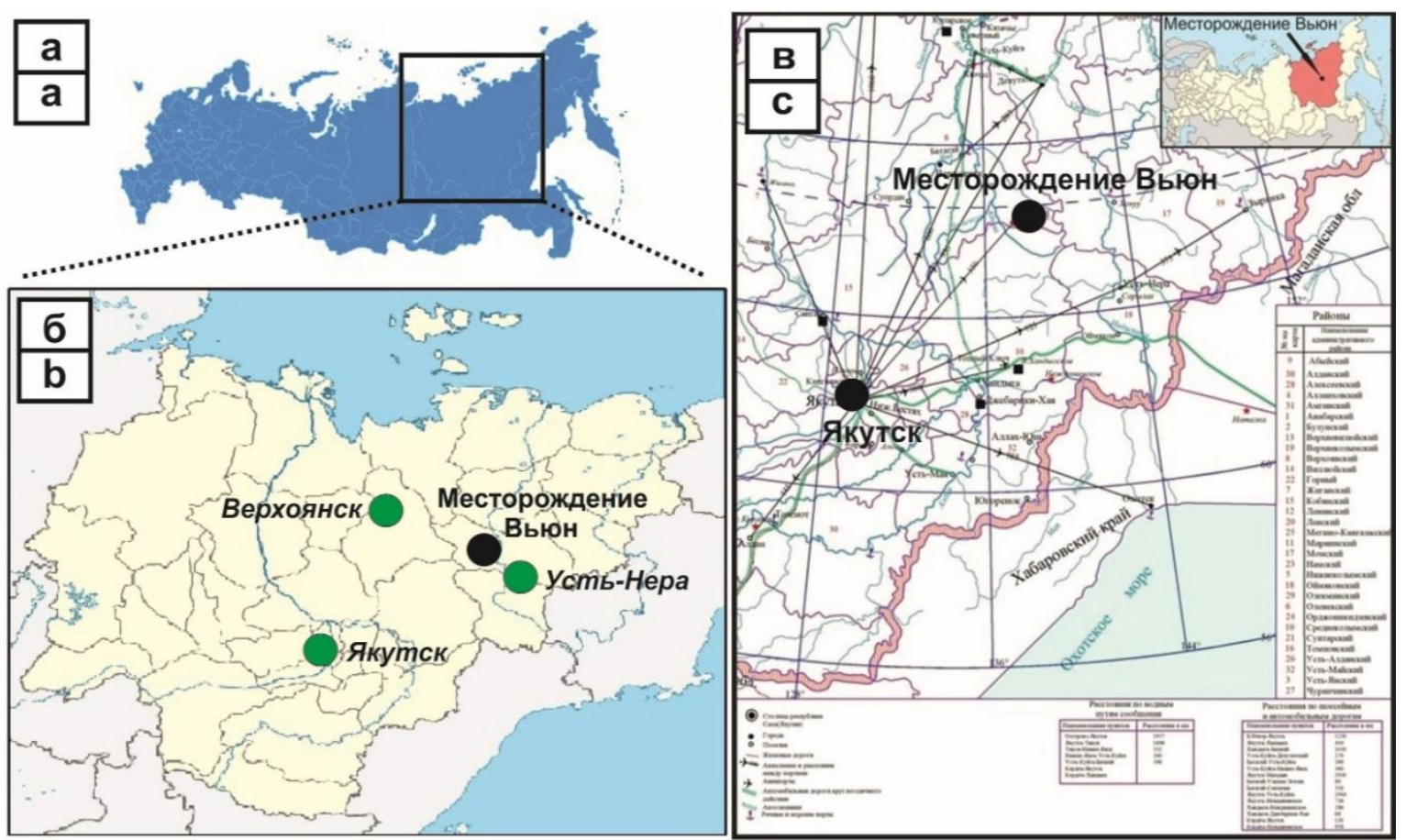

Pис. 1. Республика Саха (Якутия) на карте Российской Федераиии (а) [14] и схемы расположения золоторудного месторождения Вьюн на территории Республики (б, в) [15]

Fig. 1. The Republic of Sakha (Yakutia) on the map of the Russian Federation (a) [14] and the location of the Vyun gold deposit on the territory of the Republic $(b, c)[15]$

Район месторождения характеризуется среднегорным рельефом, который местами доходит до высокогорного, относится к субарктической зоне с суровым резко-континентальным климатом.

В районе месторождения наблюдается сплошное распространение многолетнемерзлых пород мощностью от 200 до 350 м. Глубина сезонного протаивания грунтов не превышает 1 м [13].

Поверхностные воды представлены горным ручьём Вьюн, его притоками (временные водотоки) и рекой Бурганджа, которая является правым притоком реки Эльгенджа (верховье бассейна реки Джолакаг). В совокупности данные водотоки относятся к правобережному бассейну реки Адычи, которая является правым притоком реки Яны.
Водотоки характеризуются быстрым течением, незначительной глубиной и отличаются крайне непостоянным в зависимости от сезона режимом.

В геологическом плане золоторудное месторождение Вьюн входит в состав Эльгенджинского руднороссыпного узла Адычанской золотоносной зоны, а в более широком смысле является частью ЯноКолымского пояса [8].

Территорию месторождения слагают терригенные отложения (аргиллиты, алевролиты) верхнетриасового возраста, которые располагаются в периферической части надинтрузивной зоны невскрытого Бурганджинского гранитоидного массива. В границах месторождения установлены дайки кислого состава раннемелового возраста. 
Рудоносная структура месторождения Вьюн представлена кварцево-жильной зоной и характеризуется малосульфидными золотокварцевыми рудами. Промышленная золотоносность руд определяется золотопирит-арсенопиритовым и золото-халькопиритгаленитовым парагенезисами. Главным минералом руд является жильный кварц с включениями золота [8, 13].

Геоэкологические особенности территории месторождения Вьюн являются типичными для территорий горнопромышленного освоения Республики Саха (Якутия) в целом. В границах исследуемой территории геоэкологическая обстановка определяется, прежде всего, совокупностью природных (геологических, геоморфологических, геохимических, мерзлотногидрогеологических и инженерно-криогеологических) факторов, формирующих современные ландшафты. В пределах месторождения отсутствуют памятники археологии, особо охраняемые территории и другие объекты, ограничивающие строительство горнодобывающего предприятия (заповедники, заказники, земли историко-культурного назначения, курортные зоны и зоны отдыха).

По данным экологического районирования России территория золоторудного месторождения Вьюн относится к Верхояно-Колымскому экорегиону и имеет II (низкий) ранг экологической напряжённости. Доминирующим фактором влияния на остроту экологической обстановки является распространённость многолетнемёрзлых пород [16].

\section{Методика проведения работ}

На территории золоторудного месторождения Вьюн в летний период 2017 г. были проведены комплексные эколого-геохимические исследования, организованные в соответствии с требованиями «Методических рекомендаций по применению Классифика- ции запасов месторождений и прогнозных ресурсов твердых полезных ископаемых. Золото рудное», утвержденных распоряжением Министерства природных ресурсов России от 05.06.2007 г. Экологогеохимические работы на месторождении проводись с соблюдением существующих методических подходов и рекомендаций для такого вида исследований $[17,18]$. Отбор проб компонентов природной среды осуществлялся в строгом соответствии с нормативными документами, регламентирующими процедуры пробоотбора, с фиксацией координат расположения точек опробования и погодных условий на момент проведения работ.

Лабораторно-аналитические работы для установления химического и элементного составов отобранных проб производились в аккредитованных лабораториях г. Томска по аттестованным методикам.

В данной работе обсуждаются результаты гидрогеохимического опробования природных поверхностных вод водотоков. Отбор проб воды на территории золоторудного месторождения Вьюн осуществлялся из четырех водотоков: ручья Вьюн (6 проб воды); правого притока ручья Вьюн (2 пробы); левого притока ручья Вьюн (2 пробы); реки Бурганджа (3 пробы).

Всего было отобрано и изучено 13 проб природных поверхностных вод.

Расположение пунктов отбора проб показано на рис. 2.

Предварительная подготовка проб воды заключалась в их консервации для определения таких показателей, как химическое потребление кислорода (ХПК) (консервант - серная кислота), $\mathrm{NO}_{3}{ }^{-}, \mathrm{NO}_{2}^{-}, \mathrm{NH}_{4}{ }^{+}, \mathrm{PO}_{4}{ }^{3-}$ (консервант - хлороформ). Для определения гидрохимических показателей и содержаний химических элементов консервация проб воды не требовалась.
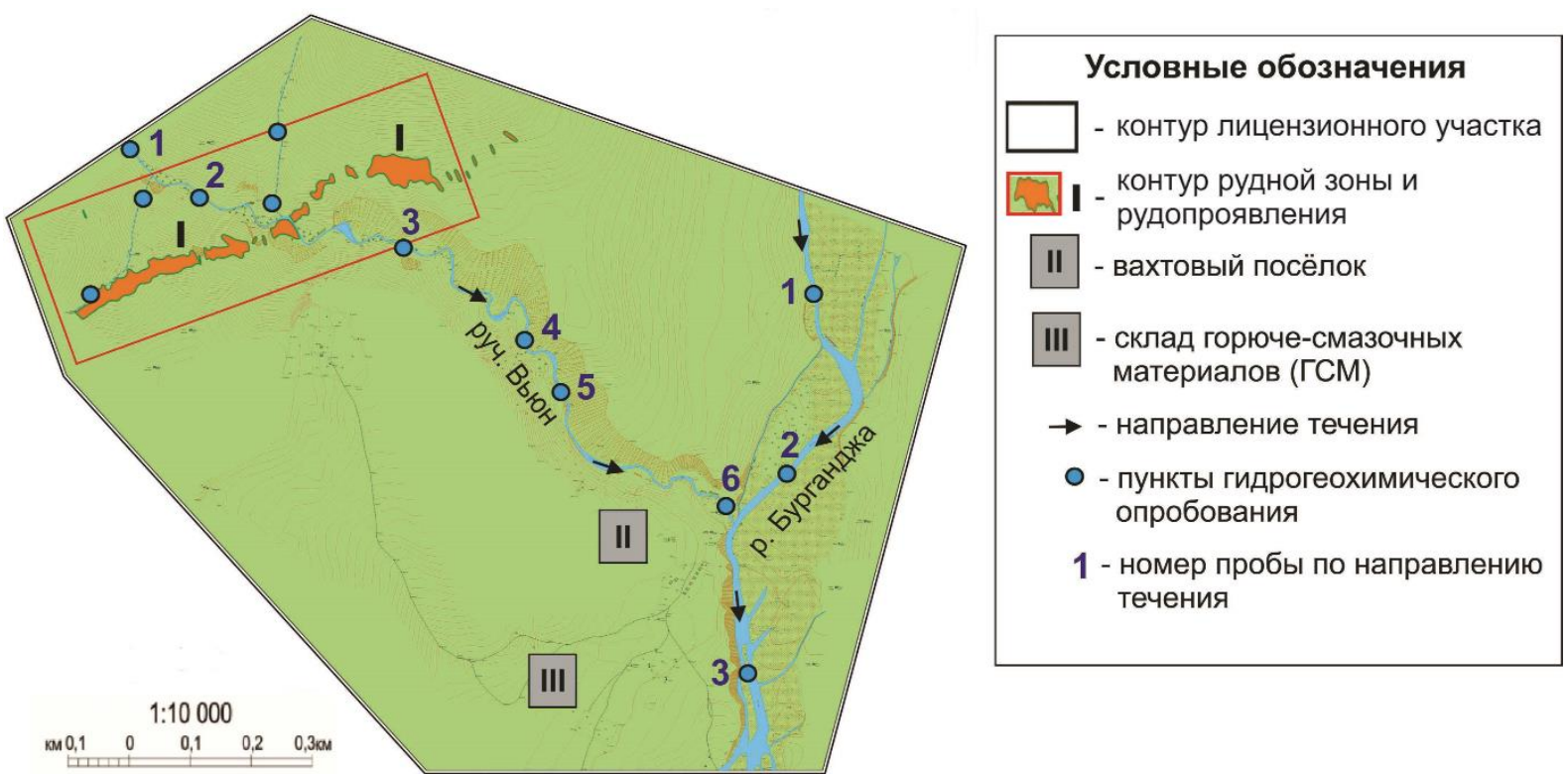

Рис. 2. Схема пунктов гидрогеохимического опробования водотоков золоторудного месторождения Вьюн

Fig. 2. Scheme of places for hydrogeochemical watercourses sampling of the Vyun gold ore deposit area 
Элементный анализ проб на содержание 71 химического элемента (Li, Be, B, Na, Mg, Al, Si, P, K, Ca, $\mathrm{Sc}, \mathrm{Ti}, \mathrm{V}, \mathrm{Cr}, \mathrm{Mn}, \mathrm{Fe}, \mathrm{Co}, \mathrm{Ni}, \mathrm{Cu}, \mathrm{Zn}, \mathrm{Ga}, \mathrm{Ge}, \mathrm{As}, \mathrm{Se}, \mathrm{Br}$, $\mathrm{Rb}, \mathrm{Sr}, \mathrm{Y}, \mathrm{Zr}, \mathrm{Nb}, \mathrm{Mo}, \mathrm{Ru}, \mathrm{Rh}, \mathrm{Pd}, \mathrm{Ag}, \mathrm{Cd}, \mathrm{In}, \mathrm{Sn}, \mathrm{Sb}$, Te, I, Cs, Ba, La, Ce, Pr, Nd, Sm, Eu, Gd, Tb, Dy, Ho, Er, Tm, Yb, Lu, Hf, Ta, W, Re, Os, Ir, Pt, Au, Hg, Tl, Pb, Bi, Th и U) проводился методом масс-спектрометрии с индуктивно связанной плазмой (ICP-MS) в аккредитованной Проблемной научно-исследовательской лаборатории гидрогеохимии НОЦ «Вода» отделения геологии Инженерной школы природных ресурсов Томского политехнического университета.

Для установления химических характеристик природных поверхностных вод образцы были проанализированы комплексом методов: титриметрическим $\left(\mathrm{CO}_{2}, \mathrm{CO}_{3}{ }^{2-}, \mathrm{HCO}_{3}^{-}, \mathrm{Cl}^{-}\right.$, общая жесткость, $\left.\mathrm{Ca}^{2+}, \mathrm{X \Pi К}\right)$; потенциометрическим ( $\left.\mathrm{pH}, \mathrm{F}^{-}\right)$; кондуктометрическим (электропроводность); гравиметрическим (взвешенные вещества); фотоколориметрическим $\left(\mathrm{NH}_{4}{ }^{+}, \mathrm{NO}_{2}{ }^{-}\right.$, $\left.\mathrm{PO}_{4}^{3-}\right)$; спектрофотометрическим $\left(\mathrm{SO}_{4}^{2-}\right)$; методом ионной хроматографии $\left(\mathrm{NO}_{3}{ }^{-}\right)$; по расчетным методикам $\left(\mathrm{Mg}^{2+}\right.$, минерализация) в НОЦ «Вода».

Статистическая обработка данных включала в себя оценку числовых характеристик содержаний химиче- ских элементов, соединений и гидрохимических показателей, анализ их распределения и выявление значимых связей между ними.

Основным результатом исследования являлось установление геохимической специализации природных поверхностных вод водотоков, с целью чего рассчитывались отношения содержаний элементов в воде к эталонному уровню, т. е. кларк концентрации химических элементов, который является показателем уровня аномальности содержаний элементов относительно того или иного критерия [18].

В данной работе при расчёте кларков концентрации химических элементов в водах водотоков в качестве эталона применялся кларк речных вод по А.П. Виноградову [19].

Обработка данных лабораторно-аналитических исследований проводилась с использованием программного комплекса Statistica 10.0.

\section{Результаты и их обсуждение}

Средние значения содержаний ионов и гидрохимических показателей в природных поверхностных водах водотоков на территории месторождения Вьюн приведены в табл. 1.

Таблица 1. Средние значения содержаний ионов и гидрохимических показателей в природных поверхностных водах водотоков на территории месторождения Вьюн

Table 1. Average values of ion contents and hydrochemical indicators in natural surface waters of streams in the territory of the Vyun field

\begin{tabular}{|c|c|c|c|c|c|}
\hline $\begin{array}{c}\text { Показатели } \\
\text { Indicators }\end{array}$ & $\begin{array}{c}\text { Единицы измерения } \\
\text { Units }\end{array}$ & $\begin{array}{l}\text { Значение } \\
\text { Value }\end{array}$ & $\begin{array}{c}\text { Показатели } \\
\text { Indicators }\end{array}$ & $\begin{array}{c}\text { Единицы измерения } \\
\text { Units }\end{array}$ & $\begin{array}{l}\text { Значение } \\
\text { Value }\end{array}$ \\
\hline $\mathrm{pH}$ & Единицы pH/Units $\mathrm{pH}$ & $7,1 \pm 0,1$ & Мин. & мГ/л & $32,2 \pm 4,1$ \\
\hline $\mathrm{CO}_{2}$ & \multirow{4}{*}{$\begin{array}{l}\mathrm{мг/л} \\
\mathrm{mg} / \mathrm{l}\end{array}$} & $4,87 \pm 0,29$ & ХПК & $\mathrm{mg} / \mathrm{l}$ & $16,2 \pm 1,9$ \\
\hline $\mathrm{HCO}_{3}^{-}$ & & $15,4 \pm 3,1$ & Эл-ть & мСм $/ \mathrm{cm} / \mathrm{mSm} / \mathrm{cm}$ & $0,05 \pm 0,003$ \\
\hline $\mathrm{SO}_{4}^{2-}$ & & $7,69 \pm 1,11$ & $\mathrm{BB}$ & \multirow{4}{*}{$\begin{array}{l}\mathrm{мг} / \text { л } \\
\mathrm{mg} / \mathrm{l}\end{array}$} & $1,99 \pm 0,44$ \\
\hline $\mathrm{Cl}^{-}$ & & $0,56 \pm 0,06$ & $\mathrm{NH}_{4}^{+}$ & & $0,36 \pm 0,08$ \\
\hline ОЖ & $\begin{array}{l}\text { ммоль-экв./л. } \\
\text { mmol-equiv./l }\end{array}$ & $0,57 \pm 0,06$ & $\mathrm{NO}_{3}^{-}$ & & $0,65 \pm 0,06$ \\
\hline $\mathrm{Ca}^{2+}$ & \multirow{2}{*}{$\begin{array}{l}\mathrm{M \Gamma} / \mathrm{\pi} \\
\mathrm{mg} / \mathrm{l}\end{array}$} & $6,93 \pm 0,73$ & $\mathrm{PO}_{4}{ }^{3-}$ & & $0,19 \pm 0,007$ \\
\hline $\mathrm{Mg}^{2+}$ & & $2,68 \pm 0,28$ & $\begin{array}{llll}- & \\
\end{array}$ & - & - \\
\hline \multicolumn{5}{|c|}{ Количество проб/Number of samples } & 13 \\
\hline
\end{tabular}

Примечание. 1) ОЖ - общая жесткость; 2) Мин. - минерализация; 3) Эл-ть - электропроводность; 4) BВ - взвешенные вещества. Среднее значение 士стандартная ошибка, аномальные значения при расчете средних не учитывались. Содержсания $\mathrm{CO}_{3}{ }^{2-}, \mathrm{NO}_{2}^{-}$ниже предела обнаружения.

Notes. 1) ОЖ - general hardness; 2) Мин. - mineralization; 3) Эл-ть - electrical conductivity; 4) BВ - suspended solids. Mean value \pm standard error, abnormal values were not taken into account when calculating the means. The content of $\mathrm{CO}_{3}{ }^{2-}$, $\mathrm{NO}_{2}{ }^{-}$is below the detection limit.

В качестве средних значений изучаемых показателей в природных водах месторождения были приняты средние арифметические значения.

В ходе статистической обработки данных о содержаниях ионов, химических элементов, а также величин значений гидрохимических показателей выявлено, что наименьшей вариативностью в природных поверхностных водах месторождения Вьюн характеризуются показатели $\mathrm{pH}$ и электропроводность, а также $\mathrm{CO}_{2}$. Повышенные значения коэффициента вариации (36-49 \%) в пробах воды из водотоков характерны для ХПК, минерализации и концентраций некоторых ионов $\left(\mathrm{Cl}^{-}, \mathrm{Ca}^{2+}, \mathrm{Mg}^{2+}\right)$.

Разброс концентраций изучаемых компонентов иллюстрирует диаграмма размаха (рис. 3).
Проведённые исследования показали, что по значению водородного показателя природные поверхностные воды месторождения являются преимущественно нейтральными со значением $\mathrm{pH}$ около 7,0 (исключение составляют лишь слабокислые воды правого притока ручья Вьюн с $\mathrm{pH}$ 6,4), характеризуются как ультрапресные и очень мягкие.

Воды в исследованных водотоках разделяются на два типа: сульфатно-гидрокарбонатный магниевокальциевый (левый приток ручья Вьюн, ручей Вьюн и река Бурганджа) и гидрокарбонатно-сульфатный магниево-кальциевый (правый приток ручья Вьюн). Различие данных типов вод заключается в небольшой разнице во взаимозамещении анионов $\mathrm{HCO}_{3}{ }^{-}$и $\mathrm{SO}_{4}{ }^{2-}$. 


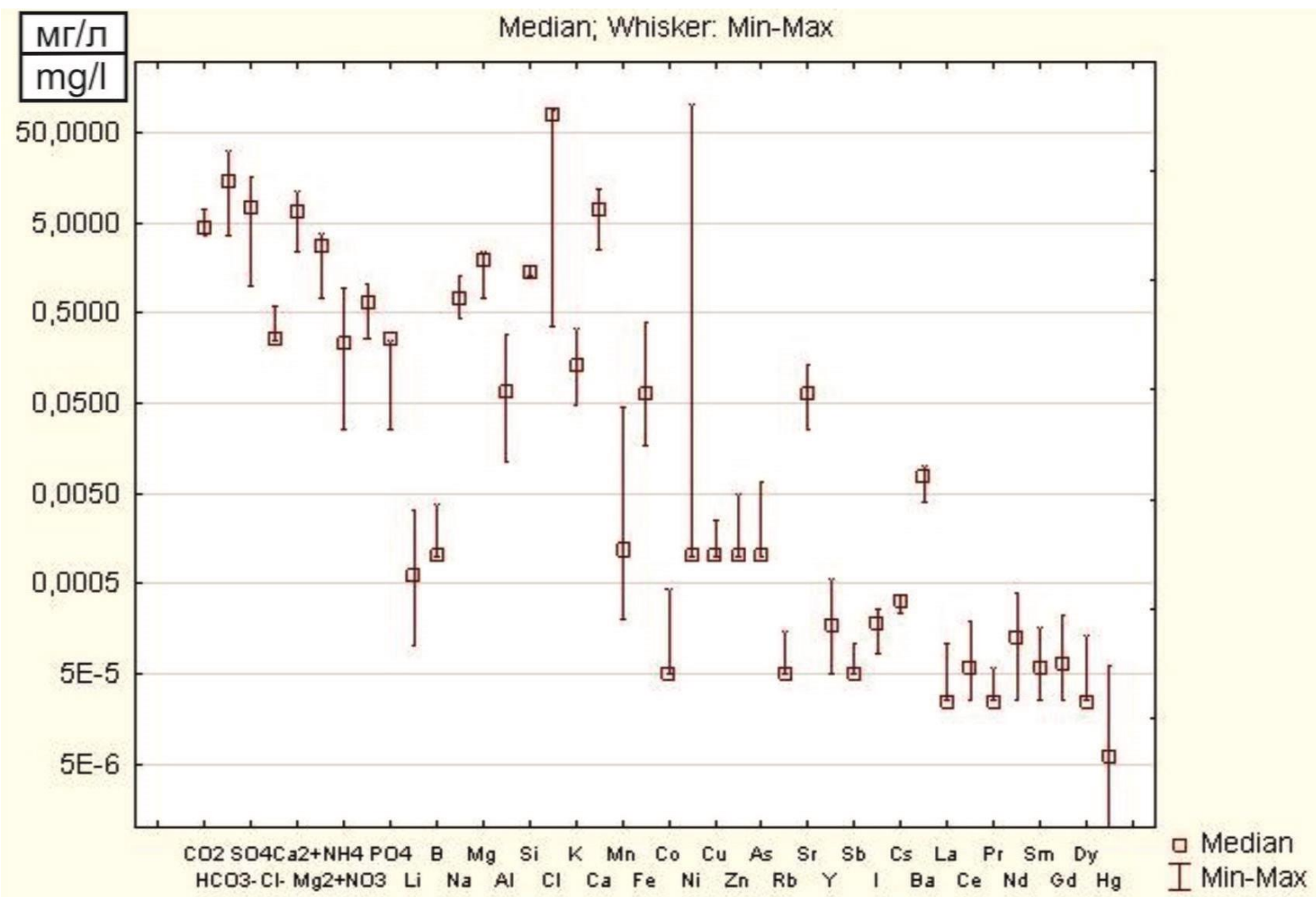

Рис. 3. Диаграмма размаха содержаний изучаемых компонентов в природных поверхностных водах водотоков месторождения Вьюн

Fig. 3. Range of contents values of the studied components in natural surface watercourses of in Vyun deposit

Тип природных поверхностных вод ручьев и рек месторождения по катионной составляющей устойчив - воды являются магниево-кальциевыми с незначительной вариабельностью соотношения ионов кальция и магния.

В табл. 2 представлены характеристики вод водотоков территории месторождения Вьюн, выраженные с помощью формулы Курлова, которая учитывает анионный и катионный состав воды, а также некоторые гидрохимические показатели и является стандартным видом записи информации о природной воде [20].

Повышение балансовой доли сульфат-иона в природных поверхностных водах является следствием контакта вод с участками сульфидной минерализации - зоной локализации рудного тела месторождения, для которой характерна окислительная обстановка. Кроме того, увеличению доли сульфатов в солевом составе рек и ручьёв способствует разгрузка подмерзлотных вод в долинах водотоков [3].

Также на изменчивость химического состава поверхностных вод влияет поступление растворимых веществ из атмосферы. По данным В.Н. Макарова [3], для Верхнеиндигирского золотоносного района Якутии характерна средняя минерализация осадков 15 мг/л. Их вклад в привнос солей в поверхностные воды достигает $50 \%$.

Средние содержания ионов и значений гидрохимических показателей вод водотоков месторождения
Вьюн были сопоставлены с данными М.И. Ксенофонтовой [21] о региональных фоновых гидрохимических параметрах бассейна реки Яна, к которому относится речная сеть исследуемой территории. Фоновые данные были получены сотрудниками СевероВосточного федерального университета (СВФУ) им. М.К. Аммосова в ходе комплексных экологических исследований в бассейне верхнего течения реки Яна в 2015-2017 гг.

Выявлено, что фоновый показатель минерализации, а также $\mathrm{pH}$ и жёсткость имеют близкие к полученным в ходе данных исследований значениям.

Содержания $\mathrm{Ca}^{2+}\left(6,93 \mathrm{мг/л),} \mathrm{Mg}^{2+}(2,68 \mathrm{мг/л)}\right.$, $\mathrm{HCO}_{3}{ }^{-}$(15,4 мг/л) для опробованных водотоков выше, чем региональные фоновые $(4,0,1,7$ и 6,7 мг/л соответственно), в то время как фоновые значения содержаний взвешенных веществ $(42,2 \mathrm{Mг} / л)$, а также $\mathrm{SO}_{4}{ }^{2-}$ $(15,5$ мг/л) существенно превышают средние содержания данных компонентов в водотоках месторождения Вьюн (1,99 и 7,69 мг/л соответственно). Причиной этому могут служить процессы интенсивного поступления минерального вещества в реку Яна и её притоки, в бассейнах которых ведутся горнодобычные работы.

Средние содержания химических элементов в природных поверхностных водах водотоков на территории месторождения Вьюн приведены в табл. 3. 
Таблица 2. Характеристики природных поверхностных вод водотоков территории золоторудного месторождения Вьюн по гидрохимическим показателям

Table 2. Characteristics of natural surface waters of watercourses in the territory of the Vyun gold ore deposit according to hydrochemical parameters

\begin{tabular}{|c|c|c|}
\hline $\begin{array}{c}\text { Водоток } \\
\text { Watercourse }\end{array}$ & $\begin{array}{l}\text { Число проб } \\
\text { Number } \\
\text { of samples }\end{array}$ & $\begin{array}{l}\text { Формула Курлова/Характеристика воды } \\
\text { Kurlov's formula/Water characteristic }\end{array}$ \\
\hline \multirow{2}{*}{$\begin{array}{l}\text { Правый приток ру- } \\
\text { чья Вьюн } \\
\text { Right tributary of the } \\
\text { Vyun stream }\end{array}$} & \multirow[b]{2}{*}{2} & $\mathrm{~S} 4,3 \mathrm{CO}_{2} 7,0 \mathrm{M} 29 \frac{\mathrm{SO}_{4} 80 \mathrm{HCO}_{3} 20}{\mathrm{Ca} 58 \mathrm{Mg} 39 \mathrm{Na} 3} \mathrm{pH} 6,4 \mathrm{~T} 2,7$ \\
\hline & & $\begin{array}{l}\text { Ультрапресная, гидрокарбонатно-сульфатная магниево-кальциевая, слабо кислая, очень } \\
\text { мягкая, весьма холодная } \\
\text { Ultra-fresh, bicarbonate-sulfate magnesium-calcium, slightly acidic, very soft, very cold }\end{array}$ \\
\hline \multirow{2}{*}{$\begin{array}{l}\text { Левый приток ручья } \\
\text { Вьюн } \\
\text { Left tributary of the } \\
\text { Vyun stream }\end{array}$} & \multirow[b]{2}{*}{2} & S0,8 $\mathrm{CO}_{2} 5,3 \mathrm{M} 12 \frac{\mathrm{HCO}_{3} 77 \mathrm{SO}_{4} 23}{\mathrm{Ca} 59 \mathrm{Mg} 29 \mathrm{Na} 12} \mathrm{pH} 7,0 \mathrm{~T} 4,0$ \\
\hline & & $\begin{array}{l}\text { Ультрапресная, сульфатно-гидрокарбонатная магниево-кальциевая, нейтральная, очень } \\
\text { мягкая, умеренно холодная } \\
\text { Ultra-fresh, sulfate-bicarbonate magnesium-calcium, neutral, very soft, moderately cold }\end{array}$ \\
\hline \multirow{2}{*}{$\begin{array}{l}\text { Ручей Вьюн } \\
\text { Vyun Stream }\end{array}$} & \multirow[b]{2}{*}{6} & $\mathrm{~S} 0,5 \mathrm{CO}_{2} 4,3 \mathrm{M} 30 \frac{\mathrm{HCO}_{3} 57 \mathrm{SO}_{4} 43}{\mathrm{Ca} 56 \mathrm{Mg} 38 \mathrm{Na} 6} \mathrm{pH} 7,2 \mathrm{~T} 5,0$ \\
\hline & & $\begin{array}{l}\text { Ультрапресная, сульфатно-гидрокарбонатная магниево-кальциевая, нейтральная, очень } \\
\text { мягкая, умеренно холодная } \\
\text { Ultra-fresh, sulfate-bicarbonate magnesium-calcium, neutral, very soft, moderately cold }\end{array}$ \\
\hline \multirow{2}{*}{$\begin{array}{l}\text { Река Бурганджа } \\
\text { Burgandja river }\end{array}$} & \multirow[b]{2}{*}{3} & $\mathrm{S0}, 3 \mathrm{CO}_{2} 4,4 \mathrm{M} 52 \frac{\mathrm{HCO}_{3} 77 \mathrm{SO}_{4} 23}{\mathrm{Ca} 60 \mathrm{Mg} 33 \mathrm{Na} 7} \mathrm{pH} 7,5 \mathrm{~T} 8,1$ \\
\hline & & $\begin{array}{l}\text { Ультрапресная, сульфатно-гидрокарбонатная магниево-кальциевая, нейтральная, очень } \\
\text { мягкая, умеренно холодная } \\
\text { Ultra-fresh, sulfate-bicarbonate magnesium-calcium, neutral, very soft, moderately cold }\end{array}$ \\
\hline \multirow{2}{*}{$\begin{array}{l}\text { Общее для всех во- } \\
\text { дотоков } \\
\text { Common to all water- } \\
\text { courses }\end{array}$} & \multirow[b]{2}{*}{13} & $\mathrm{~S} 1,5 \mathrm{CO}_{2} 5,3 \mathrm{M} 31 \frac{\mathrm{HCO}_{3} 59 \mathrm{SO}_{4} 41}{\mathrm{Ca} 58 \mathrm{Mg} 35 \mathrm{Na} 7} \mathrm{pH} 7,0 \mathrm{~T} 5,0$ \\
\hline & & $\begin{array}{l}\text { Ультрапресная, сульфатно-гидрокарбонатная магниево-кальциевая, нейтральная, очень } \\
\text { мягкая, умеренно холодная } \\
\text { Ultra-fresh, sulfate-bicarbonate magnesium-calcium, neutral, very soft, moderately cold }\end{array}$ \\
\hline
\end{tabular}

Примечание. $S$ - содержание нерастворимых примесей (мг/л); $M-$ минерализаиия (мг/л); $p H-$ водородный показатель (ед.); $\mathrm{T}$ - температура $\left({ }^{\circ} \mathrm{C}\right)$. Содержание $\mathrm{CO}_{2}$ приведено в мг/л; содержания $\mathrm{HCO}_{3}^{-}, \mathrm{SO}_{4}^{2-}, \mathrm{Ca}^{2+}, \mathrm{Mg}^{2+}$, $\mathrm{Na}^{+}$приведены в мг-экв. \%.

Note. $S$ is the content of insoluble impurities ( $m g / l) ; M$ is the mineralization ( $m g / l) ; p H-p H$ value (units $p H)$; $T$ is the temperature $\left({ }^{\circ} \mathrm{C}\right) . \mathrm{CO}_{2}$ content is given in $\mathrm{mg} / \mathrm{l}$; the contents of $\mathrm{HCO}_{3}^{-}, \mathrm{SO}_{4}^{2-}, \mathrm{Ca}^{2+}, \mathrm{Mg}^{2+}, \mathrm{Na}^{+}$are given in $\mathrm{mg}$.-equiv. \%.

Таблица 3. Средние содержания химических элементов в природных поверхностных водах водотоков на территории месторождения Вьюн

Table 3. Average concentrations of chemical elements in natural surface watercourses in the Vyun field

\begin{tabular}{|c|c|c|c|c|c|}
\hline $\begin{array}{c}\text { Показатели } \\
\text { Indicators }\end{array}$ & $\begin{array}{c}\text { Единицы измерения } \\
\text { Units }\end{array}$ & $\begin{array}{l}\text { Значение } \\
\text { Value }\end{array}$ & $\begin{array}{c}\text { Показатели } \\
\text { Indicators }\end{array}$ & $\begin{array}{c}\text { Единицы измерения } \\
\text { Units }\end{array}$ & $\begin{array}{c}\text { Значение } \\
\text { Value }\end{array}$ \\
\hline $\mathrm{Li}$ & \multirow{2}{*}{$\begin{array}{l}\mathrm{M \kappa г} / л \\
\mathrm{mcg} / \mathrm{l}\end{array}$} & $0,89 \pm 0,27$ & $\mathrm{Rb}$ & \multirow{16}{*}{ мкг/л mcg/l } & $0,02 \pm 0,005$ \\
\hline B & & $0,35 \pm 0,08$ & $\mathrm{Sr}$ & & $71,5 \pm 8,7$ \\
\hline $\mathrm{Na}$ & \multirow{2}{*}{$\begin{array}{l}\mathrm{M \Gamma} / \mathrm{л} \\
\mathrm{mg} / \mathrm{l}\end{array}$} & $0,79 \pm 0,09$ & $\mathrm{Y}$ & & $0,2 \pm 0,05$ \\
\hline $\mathrm{Mg}$ & & $1,75 \pm 0,15$ & $\mathrm{Sb}$ & & $0,02 \pm 0,007$ \\
\hline $\mathrm{Al}$ & $\begin{array}{l}\text { мкг/л } \\
\mathrm{mcg} / 1\end{array}$ & $83,8 \pm 22,3$ & I & & $0,18 \pm 0,01$ \\
\hline $\mathrm{Si}$ & \multirow{3}{*}{$\begin{array}{l}\mathrm{Mг} / \text { л } \\
\mathrm{mg} / \mathrm{l}\end{array}$} & $1,42 \pm 0,03$ & Cs & & $\mathbf{0 , 3 1} \pm \mathbf{0 , 0 1}$ \\
\hline $\mathrm{K}$ & & $0,17 \pm 27$ & $\mathrm{Ba}$ & & $7,62 \pm 0,49$ \\
\hline $\mathrm{Ca}$ & & $7,27 \pm 0,83$ & $\mathrm{La}$ & & $0,01 \pm 0,004$ \\
\hline $\mathrm{Mn}$ & \multirow{7}{*}{$\begin{array}{l}\text { мкг/л } \\
\mathrm{mcg} / \mathrm{l}\end{array}$} & $6,89 \pm 4,1$ & $\mathrm{Ce}$ & & $0,06 \pm 0,01$ \\
\hline $\mathbf{F e}$ & & $96,1 \pm 33,6$ & Pr & & $0,01 \pm 0,006$ \\
\hline Co & & $0,06 \pm 0,01$ & Nd & & $0,15 \pm 0,03$ \\
\hline $\mathrm{Ni}$ & & $0,64 \pm 0,13$ & Sm & & $\mathbf{0 , 0 5} \pm \mathbf{0 , 0 1}$ \\
\hline $\mathrm{Cu}$ & & $0,37 \pm 0,08$ & Gd & & $\mathbf{0 , 0 7 \pm 0 , 0 1}$ \\
\hline $\mathrm{Zn}$ & & $0,69 \pm 0,11$ & Dy & & $0,02 \pm 0,006$ \\
\hline As & & $1,46 \pm 0,66$ & $\mathrm{Hg}$ & & $0,02 \pm 0,006$ \\
\hline \multicolumn{4}{|c|}{ Количество проб/Number of samples } & & 13 \\
\hline
\end{tabular}

Примечание. Содержания $\mathrm{F}, \mathrm{Be}, \mathrm{P}, \mathrm{Sc}, \mathrm{Ti}, \mathrm{Cr}, \mathrm{Ga}, \mathrm{Ge}, \mathrm{Se}, \mathrm{Br}, \mathrm{Zr}, \mathrm{Nb}, \mathrm{Mo}, \mathrm{Ru}, \mathrm{Rh}, \mathrm{Pd}, \mathrm{Ag}, \mathrm{Cd}, \mathrm{In}, \mathrm{Sn}, \mathrm{Te}, \mathrm{Eu}, \mathrm{Tb}, \mathrm{Ho}, \mathrm{Er}$, $\mathrm{Tm}, \mathrm{Yb}, \mathrm{Lu}, \mathrm{Hf}, \mathrm{Ta}, \mathrm{W}, \mathrm{Re}, \mathrm{Os}, \mathrm{Ir}, \mathrm{Pt}, \mathrm{Au}, \mathrm{Tl}, \mathrm{Pb}, \mathrm{Bi}, \mathrm{Th}, \mathrm{U}$ ниже предела обнаружения. Среднее значение \pm стандартная ошибка, аномальные значения при расчете средних не учитывались. Жирным шрифтом выделены средние содержания химических элементов в поверхностных водах водотоков, превышающие кларк речных вод по Виноградову [19].

Note. Contents of $F, B e, P, S c, T i, C r, G a, G e, S e, B r, Z r, N b, M o, R u, R h, P d, A g, C d, I n, S n, T e, E u, T b, H o, E r, T m, Y b, L u$, $\mathrm{Hf}, \mathrm{Ta}, \mathrm{W}, \mathrm{Re}, \mathrm{Os}, \mathrm{Ir}, \mathrm{Pt}, \mathrm{Au}, \mathrm{Tl}, \mathrm{Pb}, \mathrm{Bi}, \mathrm{Th}, \mathrm{U}$ are below the detection limit. Mean value \pm standard error, abnormal values were not taken into account when calculating the means. The average concentrations of chemical elements in the surface waters of streams, exceeding the clarke of river waters according to Vinogradov [19], are shown in bold. 
Статистическая обработка данных дала возможность установить, что наименьшая вариативность концентраций в водах месторождения Вьюн характерна для таких химических элементов, как $\mathrm{Si}, \mathrm{Ba}$ При этом наиболее неравномерно распределены содержания $\mathrm{Li}, \mathrm{Mn}, \mathrm{Fe}, \mathrm{Co}, \mathrm{Ni}, \mathrm{Hg}$.

Разброс концентраций химических элементов в пробах природных поверхностных вод показан на диаграмме размаха (рис. 3).

Для месторождения Вьюн важным фактором формирования химического состава природных поверхностных вод водотоков является оруденение, в связи с чем актуально проведение детальных гидрогеохимических работ, направленных на поиски золоторудной минерализации, ореолов и потоков рассеяния рудных тел. Такого рода работам сейчас уделяется большое внимание как в России [22], так и за рубежом [23, 24].

В рамках данной работы по результатам опробования водотоков установлен факт значительного увеличения концентраций специфичных для месторождения химических элементов в воде ручья Вьюн ниже по течению относительно локализации рудной зоны.

Концентрации As ниже рудной зоны возрастают в 4,7 раз (рис. 4, a), Нg - в 4 раза (рис. 4, б).
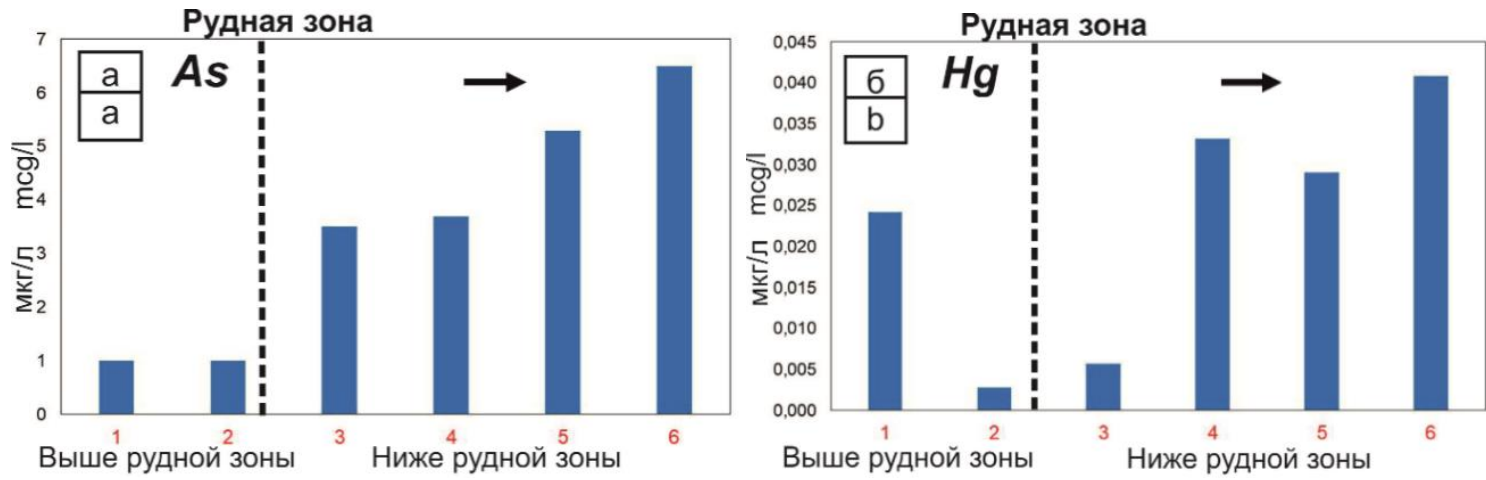

Puc. 4. Содержание As (a) и Hg (б) в воде ручья Вьюн относительно рудной зоны, мкг/л. Цифрами показаны пункты пробоотбора согласно направлению течения. Направление течения обозначено стрелкой

Fig. 4. Contents of As (a) and $\mathrm{Hg}(b)$ in the watercourses of the Vyun area relative to the ore zone, mcg/l. The numbers show the sampling points according to the direction of flow. The direction of flow is indicated by an arrow

При этом концентрации $\mathrm{Hg}$ увеличиваются в воде реки Бурганджа после впадения в нее ручья Вьюн, следовательно, можно предполагать, что ручей Вьюн оказывает влияние на химический состав вод реки Бурганджа.

Увеличение содержаний As может быть обусловлено непосредственным контактом вод ручья Вьюн с сульфидными минералами мышьяка, например с арсенопиритом (Fe[AsS]), приуроченным к рудной зоне месторождения. Кроме того, нельзя исключать контакт вод с минералами, содержащими в своём составе $\mathrm{Hg}$.

В целом особенностью вод ручья Вьюн являются повышенные относительно средних по месторождению концентрации $\mathrm{As}, \mathrm{B}, \mathrm{Sb}$ и $\mathrm{Hg}$; правого притока ручья Вьюн - $\mathrm{Co}, \mathrm{Zn}, \mathrm{Ni}, \mathrm{Cu}, \mathrm{Pb}, \mathrm{Sb}, \mathrm{Ba}$ и некоторых редкоземельных элементов (Р3Э) (Dy, La, Pr); левого притока ручья Вьюн - Si.

Для установления геохимических особенностей поверхностных вод месторождения Вьюн были рассчитаны кларки концентрации химических элементов относительно кларка речных вод по Виноградову [19] Сравнение содержаний элементов в воде с кларковыми значениями показано на рис. 5.

На основании данного графика можно говорить о том, что водотоки месторождения Вьюн характеризуются повышенными относительно кларка речных вод концентрациями Gd, Sm, Cs, Dy, Nd, Fe, Sr, Pr, формирующими общую гидрогеохимическую специализацию территории месторождения. Причём среди Р3Э преобладают те, которые имеют чётные номера в Периодической системе химических элементов
Д.И. Менделеева (Gd, Sm, Dy, Nd), в то время как уровни содержаний РЗЭ под нечётными номерами (Eu, Tb, Ho, Tm, Lu) в исследованных пробах воды находятся ниже предела обнаружения, что является отображением закона Оддо-Гаркинса.

При этом наибольшая средняя концентрация установлена для $\mathrm{Nd}$ (0,15 мг/л), а наибольшее превышение кларковых значений - для Gd (кларк концентрации 9,1 ед.).

На данный момент вопрос распространённости и поведения РЗЭ в природных поверхностных водах освещён довольно широко [25-30], при этом мало затрагивается проблема поведения РЗЭ в водах территорий распространения многолетнемёрзлых пород [31, 32].

В настоящее время известны три главных источника поступления РЗЭ в природные воды - атмосферные осадки, почвенно-растительный слой и водовмещающие горные породы.

Согласно опубликованным работам [33, 34], главными факторами, определяющими характеристики распределения и величину содержаний редких земель в донных осадках и поверхностных водотоках, являются состав исходных горных пород на территориях водосбора, процессы выветривания и почвообразования [9, 28].

Стоит отметить, что по ходу проведённых нами ранее исследований в составе проб литогенных образований месторождения Вьюн были обнаружены фосфаты РЗЭ, предположительно монацит и ксенотим, которые являются главнейшими минералами редких земель. Данный факт коррелирует с известными данными, представленными выше. 


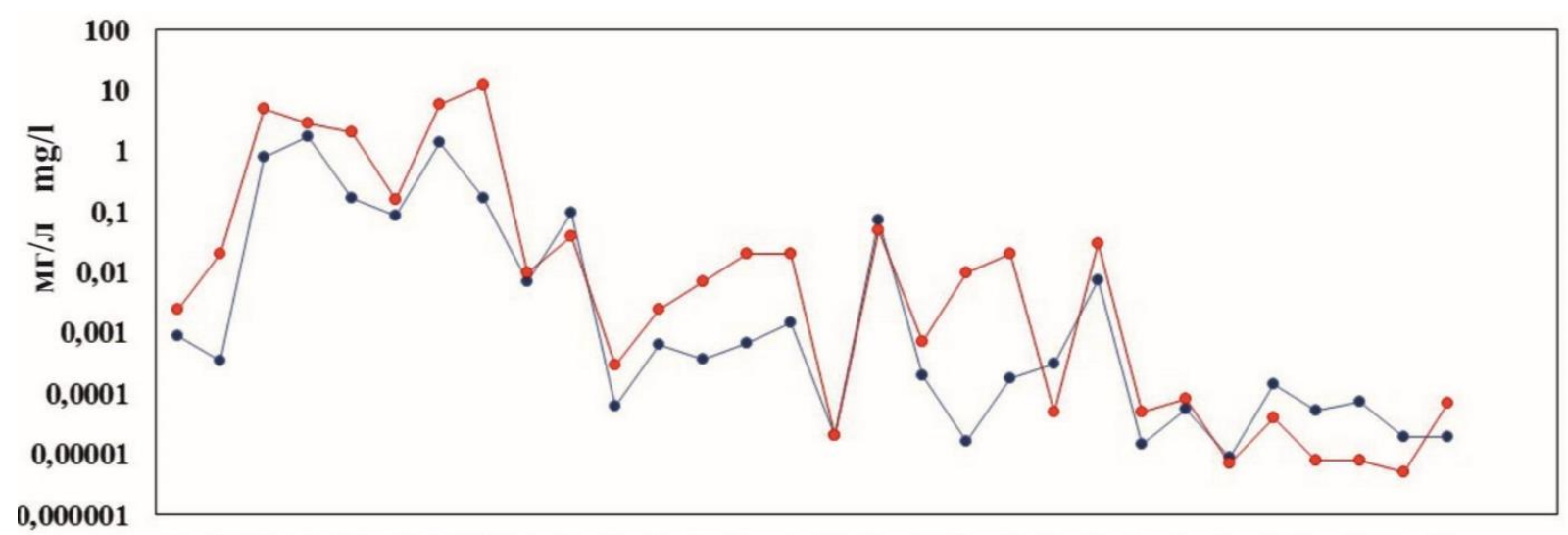

Li B NaMg K Al Si CaMn Fe Co Ni Cu Zn As Rb Sr Y Sb I Cs Ba La Ce Pr NdSmGd Dy Hg $\rightarrow \begin{aligned} & \text { Вода } \rightarrow \text { Кларк речных вод (Виноградов, 1967) } \\ & \text { Water } \\ & \text { Clark river waters (Vinogradov, 1967) }\end{aligned}$

Pис. 5. График сравнения средних содержаний химических элементов в природных поверхностных водах водотоков месторождения Вьюн с кларком речных вод по Виноградову [19] (шкала логарифмическая). Содержсания $F$, $B e, P, T i, C r, G a, G e, S e, B r, Z r, N b, M o, R u, R h, P d, A g, C d, I n, S n, T e, E u, T b, H o, E r, T m, Y b, L u, H f, T a, W, R e$, $\mathrm{Os}, \mathrm{Ir}, \mathrm{Pt}, \mathrm{Au}, \mathrm{Tl}, \mathrm{Pb}, \mathrm{Bi}, \mathrm{Th}, \mathrm{U}$ ниже предела обнаружения

Fig. 5. Graph of comparison of average contents of chemical elements in natural surface waters of the Vyun deposit with the clarke of river waters according to Vinogradov [19] (logarithmic scale). Content of $\mathrm{F}, \mathrm{Be}, \mathrm{P}, \mathrm{Ti}, \mathrm{Cr}, \mathrm{Ga}, \mathrm{Ge}, \mathrm{Se}, \mathrm{Br}$, $\mathrm{Zr}, \mathrm{Nb}, \mathrm{Mo}, \mathrm{Ru}, \mathrm{Rh}, \mathrm{Pd}, \mathrm{Ag}, \mathrm{Cd}$, In, Sn, Te, Eu, Tb, Ho, Er, Tm, Yb, Lu, Hf, Ta, W, Re, Os, Ir, Pt, Au, Tl, Pb, Bi, Th, $U$ are below the detection limit

Не менее важную роль в распространённости редких земель в поверхностных водах, вероятно, играет гидрокарбонат-ион, определяющий состав вод зоны гипергенеза месторождения и образующий комплексы с редкоземельными металлами.

Совместное присутствие в ассоциации РЗЭ и железа может быть обусловлено наличием в воде тонкодисперсных гидроксидов $\mathrm{Fe}$, представляющих собой активный сорбент [9]. Способность к комплексообразованию с такого рода сорбентами, а также с глинистыми частицами и органическим веществом, согласно экспериментальным данным [35], убывает в ряду от лёгких РЗЭ к тяжёлым и определяет подвижность лантаноидов в природных процессах [9, 28].

Более наглядно корреляция Fе и редких земель показана ниже.

В целом, касаемо вопроса миграции РЗЭ в поверхностных водах, в том числе в районах с многолетней мерзлотой и ультрапресными природными водами, которые распространены на исследуемой территории, ряд учёных отмечают особую роль органических веществ, на которых происходит перенос РЗЭ $[28,36,37]$.

Природа высоких концентраций Cs в поверхностных водах исследуемой территории требует дополнительного изучения. Как известно, природный цезий является моноизотопным элементом и состоит из одного стабильного изотопа $\mathrm{Cs}^{133}$. Остальные же изотопы Cs с массовыми числами от 112 до 151 радиоактивны и имеют техногенное происхождение. Некоторые из них являются значимыми загрязнителями окружающей среды при радиационных авариях или ядерных взрывах. Главным образом это $\mathrm{Cs}^{137}$ с периодом полураспада около 30 лет и $\mathrm{Cs}^{135} \mathrm{c}$ периодом полураспада более 2 млн лет [38].
Также стоит помнить о том, что цезий является химическим аналогом калия [39], что обуславливает его интенсивную аккумуляцию растениями, попадание в пищевые цепи, и тем самым несёт дополнительную опасность для природной среды и человека.

Опасен и радиоактивный стронций, представляющий собой химический аналог кальция [39].

Выделяются четыре природных стабильных изотопа данного химического элемента: $\mathrm{Sr}^{84}$ (изотопная распространённость составляет 0,56 \%), $\mathrm{Sr}^{86}(9,86 \%)$, $\mathrm{Sr}^{87}(7 \%), \mathrm{Sr}^{88}(82,58 \%)$ [38].

Содержания $\mathrm{Sr}$ в исследованных водотоках находятся по большей части на околокларковых уровнях, за исключением вод реки Бурганджа (кларк концентрации $\mathrm{Sr}$ составляет 2,4 ед.).

C большой долей уверенности можно утверждать о распространённости в водотоках месторождения Вьюн именно природных изотопов $\mathrm{Cs}$ и $\mathrm{Sr}$, т. к. в районе работ и на прилегающих к нему территориях отсутствуют объекты ядерно-топливного цикла (ЯТЦ), а ядерные взрывы в данной части Республики Саха (Якутия) не проводились.

Сравнивая отдельные ассоциации химических элементов ручья Вьюн, его притоков и реки Бурганджа, можно говорить о значительной их схожести. Наибольшим числом элементов, а также степенью выраженности характеризуется геохимическая специализация правого притока ручья Вьюн, который дренирует рудную зону месторождения. Обращают на себя внимание высокие концентрации Gd, Dy и Sm в водах данного водотока.

Кластеризация данных гидрогеохимического состава природных поверхностных вод водотоков золоторудного месторождения Вьюн позволила сгруппировать отдельные контролируемые показатели и выявить взаимосвязь между ними (рис. 6). 


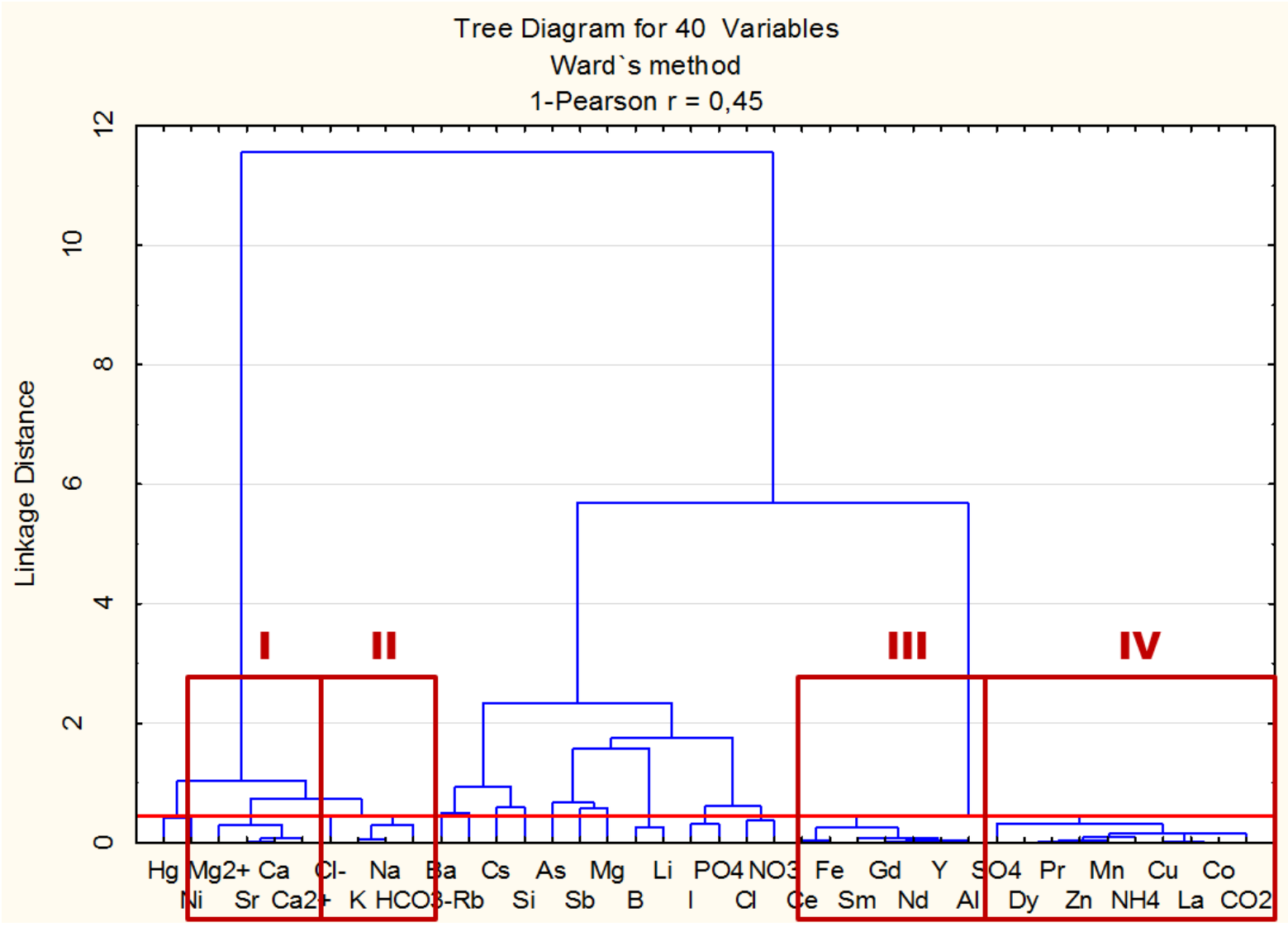

Pис. 6. Дендрограмма матрицы корреляционных связей гидрогеохимического состава природных поверхностных вод водотоков золоторудного месторождения Вьюн (количество проб - $13 ; 1-r_{0,05}=0,45$ )

Fig. 6. Dendrogram of the matrix of correlations of the hydrogeochemical composition of natural surface waters of the Vyun gold deposit (number of samples $-13 ; 1-r_{0,05}=0,45$ )

Выделяется несколько кластеров химических элементов. Первые два кластера образовывают макроэлементы: $\mathrm{Mg}^{2+}, \mathrm{Sr}, \mathrm{Ca}, \mathrm{Ca}^{2+}$ и Cl$^{-}, \mathrm{K}, \mathrm{Na}$, а также гидрокарбонат-ион, определяющий исходный тип природных вод месторождения. Третий, наиболее выделяющийся, кластер формируют $\mathrm{Fe}, \mathrm{Al}$ и $\mathrm{P} 3 Э$ (Ce, $\mathrm{Sm}$, $\mathrm{Gd}, \mathrm{Nd}, \mathrm{Y})$. В четвёртый кластер объединены сульфат-ион (индикатор контакта вод с зоной сульфидизации), халькофильные элементы $(\mathrm{Zn}, \mathrm{Cu}), \mathrm{Mn}, \mathrm{Co}$, некоторые $\mathrm{P} 3 Э$ (Dy, $\mathrm{Pr}, \mathrm{La})$, а также $\mathrm{NH}_{4}{ }^{+}$и $\mathrm{CO}_{2}$.

Третий и четвёртый кластеры отражают черты геохимической специализации водотоков месторождения.

Выделенные кластеры химических элементов в составе природных поверхностных вод водотоков на территории золоторудного месторождения Вьюн отражают парные коэффициенты корреляции (r). Так, например, значимые положительные корреляции (при уровне значимости $\mathrm{p}<0,05$ ) установлены между содержаниями $\mathrm{SO}_{4}{ }^{2-}$ c $\mathrm{Zn}(\mathrm{r}=0,86), \mathrm{Cu}(\mathrm{r}=0,86), \mathrm{Dy}$ $(\mathrm{r}=0,86), \mathrm{Mn}(\mathrm{r}=0,84), \mathrm{Co}(\mathrm{r}=0,81), \mathrm{NH}_{4}{ }^{+}(\mathrm{r}=0,72), \mathrm{CO}_{2}$ $(\mathrm{r}=0,54)$.

\section{Заключение}

Таким образом, по результатам гидрогеохимических исследований территории золоторудного месторождения Вьюн (Республика Саха (Якутия)) были определены концентрации широкого спектра химиче- ских элементов в природных поверхностных водах водотоков на доэксплуатационной стадии освоения месторождения.

Важным результатом, достигнутым по итогу выполнения гидрогеохимических работ, является установление геохимической специфики водных объектов месторождения Вьюн.

В целом для изученных вод характерна ассоциация химических элементов, основу которой составляют РЗЭ, а именно ярко выраженная гадолинийсамарий-диспрозий-неодим-празеодимовая специализация. Причём наблюдается преобладание лёгких редкоземельных элементов цериевой подгруппы.

Кроме того, водотоки месторождения Вьюн характеризуются высокими относительно кларка речных вод по Виноградову [19] уровнями концентрирования $\mathrm{Cs}, \mathrm{Fe}, \mathrm{Sr}$. Отдельные геохимические ассоциации ручья Вьюн, его притоков и реки Бурганджа схожи между собой и отражают закономерности общей гидрогеохимической специализации.

Стоит заметить, что при проведении геохимических работ в криолитозоне необходимо учитывать специфику условий, в которых происходит перераспределение вещества (влияние низких температур и льда, отсутствие объёмной водной фазы и др. [7]), особенно на территориях, приуроченных к зонам окисления сульфидных месторождений. Вокруг таких объектов в условиях вечной мерзлоты, как правило, 
формируются контрастные аномалии сопутствующих оруденению элементов с выраженной сульфатностью

[7], что и показано в данной работе.

Установленные средние уровни содержания химических элементов (включая тяжелые металлы, редкие, редкоземельные и радиоактивные химические элементы) в природных поверхностных водах территории месторождения Вьюн являются реперными значениями для последующей хозяйственной деятельно-

\section{СПИСОК ЛИТЕРАТУРЫ}

1. Погребняк Ю.Ф., Чащина Н.М., Щукина Т.М. Химический и бактериальный состав вод ореолов и потоков рассеяния кварцсульфидного месторождения // Известия АН СССР. Серия: Геология. - 1986. - № 2. - С.137-139.

2. Погребняк Ю.Ф., Кондратенко Л.А., Лапердина Т.Г. Рудные элементы в водах зоны гипергенеза месторождений Забайкалья. - Новосибирск: Наука, 1989. - 203 с.

3. Макаров В.Н. Геохимия окружающей среды Верхнеиндигирского золотоносного района // Наука и образование. - 2008. № 4. - C. 45-48.

4. Плюснин А.М., Дабаева В.В. Редкоземельные элементы в рудничных и поровых водах хвостохранилищ Джидинского и Бом-Горхонского ГОКов // XXII Совещание по подземным водам Востока России. - Новосибирск: Новосибирский государственный университет, 2018. - С. 384-388.

5. Dutova E.M. Geochemistry of fresh groundwater in the AltaiSayan folded area and adjacent areas of the West Siberian plate // Applied Geochemistry. - 2020. - V. 120. - P. 104-119.

6. Modelling of the dissolution and reprecipitation of uranium under oxidising conditions in the zone of shallow groundwater circulation / E.M. Dutova, A.N. Nikitenkov, V.D. Pokrovskiy, D. Banks, B.S. Frengstad, V.P. Parnachev // Journal of Environmental Radioactivity. - 2017. - V. 178-179. - P. 63-76.

7. Макаров В.Н. Криогенные геохимические ореолы рассеяния рудных компонентов // Наука и техника в Якутии. - 2010. № 2. - C. 9-13.

8. Государственный доклад «О состоянии и использовании минерально-сырьевых ресурсов Российской Федерации в 2016 и 2017 годах» / под ред. Е.А. Киселёва. - М.: Минерал-Инфо, 2018. $-369 \mathrm{c}$.

9. Вареничев А.А., Комогорцев Б.В., Гудзенко В.Т. Основные направления золотодобычи в России // Горный информационно-аналитический бюллетень. - 2017. - № 1. - С. 231-237.

10. Концепция новых центров экономического роста в современных условиях на примере Яно-Колымской золоторудной провинции / Б.К. Михайлов, А.И. Некрасов, О.В. Петров, С.А. Киммельман, С.Б. Михайлов // Региональная геология и металлогения. - 2010. - № 42. - С. 58-65.

11. Некрасов А.И. Типы геолого-структурных обстановок проявления золото- и сереброрудной минерализации в ЯноКолымской и Западно-Верхоянской провинциях, СевероВосток Якутии // Руды и металлы. - 2017. - № 1. - С. 5-18.

12. Геохимическая специфика редкоземельных элементов в поверхностных и подземных водах поля Албынского золоторудного месторождения (Амурская область) / В.И. Радомская, С.М. Радомский, Е.Н. Кулик, Л.И. Рогулина, Л.П. Шумилова, Л.М. Павлова // Водные ресурсы. - 2016. - Т. 43. - № 6. C. 648-660.

13. Анисимова Г.С., Протопопов Р.И. Геологическое строение и состав руд золото-кварцевого месторождения Вьюн, Восточная Якутия // Руды и металлы. - 2009. - № 5. - С. 59-69.

14. Карта России. 2015. URL: https://www.freepng.ru/png-tfycud/ (дата обращения 10.12.2020).

15. Протопопов Р.И., Сулейманов А.М., Пичугин Е.П. Подсчет запасов золоторудного месторождения Вьюн в Верхоянском улусе Республики Саха (Якутия) по состоянию на 01.01.2009, в 3-х книгах. Книга 1. - Якутск, 2009. - 175 с.

16. Экологическая ситуация в России на обзорной карте Б.И. Кочуров, А.В. Антипова, В.А. Лобковский, С.К. Костовска // Природа. - 2002. - № 12. - С. 51-56. сти и могут использоваться в дальнейшем при организации экологического мониторинга на рассматриваемой территории.

Кроме того, результаты проведённых исследований с зафиксированными ореолами рассеяния элементов-спутников малосульфидного золотокварцевого оруденения несут дополнительную информацию для недропользователей по локализации рудных $30 \mathrm{H}$.

17. Язиков Е.Г., Шатилов А.Ю. Геоэкологический мониторинг. Томск: Изд-во ТПУ, 2003. - 336 с

18. Геохимия окружающей среды / Ю.Е. Сает, Б.А. Ревич, Е.П. Янин, А.И. Ачкасов, И.Л. Башаркевич, Т.Л. Онищенко, Л.Н. Павлова, С.Ш. Саркисян, Р.С. Смирнова, Н.Я. Трефилова. - М.: Недра, 1990. - 335 c

19. Виноградов А.П. Введение в геохимию океана. - М.: Наука, 1967. $-215 \mathrm{c}$

20. Шварцев С.Л. Общая гидрогеология. - М.: Недра, 1996. - 324 с

21. Ксенофонтова М.И. Основные гидрохимические параметры поверхностных вод верхнего течения р. Яна // Проблемы региональной экологии. - 2018. - № 5. - С. 123-127.

22. Савичев О.Г. Исследование взаимосвязей между химическим составом вод и донных отложений рек Сибири // Известия Томского политехнического университета. Инжиниринг георесурсов. - 2019. - Т. 330. - № 5. - C. 178-188.

23. Noble R.P., Gray D.J. Hydrogeochemistry for mineral exploration in Western Australia (I): methods and equipment // Explore Newsletter. - 2010. - V. 146. - P. 2-11.

24. Robertson I.D.M. Geochemical exploration around the Harmony gold deposit, Peak Hill, Western Australia. Geochemistry /I Exploration, Environment, Analysis. - 2001. - V. 4. - P. 113-127.

25. Mineralogy and geochemistry of trace metals and REE in volcanic massive sulfide host rocks, stream sediments, stream waters and acid mine drainage from the Lousal mine area (Iberian Pyrite Belt, Portugal) / E. Ferreira da Silva, I. Bobos, J.X. Matos, C. Patinha, A.P. Reis, E. Cardoso Fonseca // Applied Geochemistry. - 2009. V. 24 (3). - P. 383-401.

26. Rare earth elements (REE) and yttrium in stream waters, stream sediments, and $\mathrm{Fe}-\mathrm{Mn}$ oxyhydroxides: fractio nation, speciation, and controls over REE+Y patterns in the surface environment / M.I. Leybourne, K.H. Johannesson // Geochimica et Cosmochimica Acta. - 2008. - V. 72 (24). - P. 5962-5983.

27. Biddau R., Cidu R., Frau F. Rare earth elements in waters from the albitite-bearing granodiorites of Central Sardinia, Italy // Chemical Geology. - 2002. - V. 182 (1). - P. 1- 14

28. Харитонова Н.А., Вах Е.А. Редкоземельные элементы в поверхностных водах Амурской области. Особенности накопления и фракционирования // Вестник Томского государственного университета. - 2015. - № 396. - С. 232-244.

29. Shannon W.M., Wood S.A. The analysis of pictogram quantities of rare earth elements in natural waters // Rare earth elements in groundwater flow system. - 2005. - V. 1. - P. 1-37.

30. Colloidal rare earth elements in a boreal river: changing sources and distributions during the spring flood / K. Andersson, R. Dahlqvist, D. Turner, B. Stolpe, T. Larsson, J. Ingri, P. Andersson // Geochimica et Cosmochimica Acta. - 2006. V. 70. - P. 3261-3274

31. Seasonal variability of element fluxes in two Central Siberian rivers draining high latitude permafrost dominated areas / M.L. Bagard, F. Chabaux, J. Viers, P. Stille, S. Rihs, A. Schmitt, B. Dupre // Geochimica et Cosmochimica Acta. - 2011. V. 75 (12). - P. 3335-3357.

32. Transport and transformation of riverine neodymium isotope and rare earth element signatures in high latitude estuaries: a case study from the Laptev Sea / G. Laukert, M. Frank, D. Bauch, E.C. Hathorne, M. Gutjahr, M. Janout, J. Hölemann // Earth and Planetary Science Letters. - 2017. - V. 477. - P. 205-217.

33. Viers J., Dupre B., Gaillardet J. Chemical composition of suspended sediments in World Rivers: new insights from a new database // Science of the Total Environment. - 2009. - V. 407. P. 853-868. 
34. Martin J.M., Meybeek M. Elemental mass balance of material carried by world major // Marine Chemistry. - 1979. - V. 7 (3). P. 173-206.

35. Duddy I.R. Redistribution and fractionation of the rare-earth and other elements in a weathering profile // Chemical Geology. 1980. - V. 30. - P. 363-381.

36. Ronnback P., Astroma M., Gustafsson J.P. Comparison of the behaviour of rare earth elements in surface waters, overburden groundwaters and bedrock groundwaters in two granitoidic settings, Eastern Sweden // Applied Geochemistry. - 2008. V. 23 (7). - P. 1862-1880.

37. Competitive binding of REE to humic acid and manganese oxide: Impact of reaction kinetics on development of cerium anomaly and
REE adsorption / M. Davranche, O. Pourret, G. Gruau, A. Dia, D. Jin, D. Gaertner // Chemical Geology. - 2008. - V. 247 (1). P. 154-170.

38. Meija J., Berglund M. Isotopic compositions of the elements 2013 (IUPAC Technical Report) // Pure and Applied Chemistry. 2016. - V. 88 (3). - P. 293-306.

39. Гипераккумуляция цезия ряской LEMNA MINOR / E.B. Платонова, А.В. Карташов, Д.В. Беляев, А.В. Карпычев // Известия Самарского научного центра Российской академии наук. - 2019. - Т. 21. - № 2. - С. 51-59.

Поступила 13.01.2021 2.

\section{Информация об авторах}

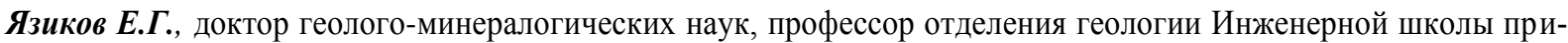
родных ресурсов Национального исследовательского Томского политехнического университета.

Мишанькин A.Ю., аспирант отделения геологии Инженерной школы природных ресурсов Национального исследовательского Томского политехнического университета.

Осипова Н.A., кандидат химических наук, доцент отделения геологии Инженерной школы природных ресурсов Национального исследовательского Томского политехнического университета.

Филимоненко E.A., кандидат геолого-минералогических наук, старший преподаватель отделения геологии Инженерной школы природных ресурсов Национального исследовательского Томского политехнического университета.

Карпенко Ю.А., аспирант отделения геологии Инженерной школы природных ресурсов Национального исследовательского Томского политехнического университета.

Собянин Ю.П., директор ООО «Богуславец». 
UDC 556.114:553.411(571.56)

\title{
GEOCHEMICAL FEATURES OF NATURAL WATERS IN THE VYUN GOLD DEPOSIT (THE REPUBLIC OF SAKHA (YAKUTIA))
}

\author{
Egor G. Yazikov' \\ yazikoveg@tpu.ru
}

\section{Andrey Yu. Mishankin ${ }^{1}$, aym13@tpu.ru}

Nina A. Osipova',
osipova@tpu.ru

\section{Ekaterina A. Filimonenko',} filimonenko@tpu.ru

Yuri A. Karpenko ${ }^{1}$, karpenkoyuriy92@gmail.com

\section{Yuri P. Sobyanin²,} yuri_sob63@mail.ru

1 National Research Tomsk Polytechnic University, 30, Lenin avenue, Tomsk, 634050, Russia.

2 LLC Boguslavets,

18, Kirov street, Yakutsk, 677027, Russia.

The relevance of the research is justified by the need in data on the state of natural surface waters in the territories of gold mining enterprises located in the permafrost zone of the subarctic belt.

The purpose of the research is to identify the geochemical properties of natural waters in the territory of Vyun gold deposit at the stage of pre-production development.

Object: surface waters of the Vyun gold deposit.

Factual materials and research methods. The factual material was obtained as a result of research work carried out in 2017 by the Department of Geoecology and Geochemistry of National Research Tomsk Polytechnic University. This paper discusses the study of watercourses in the territory of Vyun gold deposit on the basis of 13 water samples taken in the area. The samples were taken and processed using standard methods in accordance with regulation documents. The elemental composition of water was determined in the accredited Problems Research Laboratory of hydrogeochemistry of the Scientific and Educational Center "Voda» of the National Research Tomsk Polytechnic University. Contents of 71 chemical elements were determined by the method of inductively coupled plasma mass spectrometry. A number of methods were used for establishing the hydrochemical characteristics of the waters. More specifically the samples were analyzed by following methods: titrimetric; potentiometric; conductometric; gravimetric; photocolorimetric; spectrophotometric; by ion chromatographic. The calculation methods and codes developed in Scientific and Educational Center «Voda» were used as well. The results were processed using Microsoft Excel and Statistica. Schemes and diagrams were performed by the graphics editor Corel Draw.

Results. The geochemical features of the natural watercourses of the Vyun gold ore deposit area under permafrost conditions were specified. The presence of contrast anomalies of chemical elements represented by arsenic and mercury was established. These elements are satellites of low-sulfide gold quartz mineralization.

\section{Key words:}

Vyun gold ore deposit, surface waters, hydrogeochemical parameters, elemental composition, geochemical features.

\section{REFERENCES}

1. Pogrebnyak Yu.F., Chashchina N.M., Shchukina T.M. Khimicheskiy i bakterialny sostav vod oreolov i potokov rasseyaniya kvarts-sulfidnogo mestorozhdeniya [Chemical and bacterial composition of the waters of the halos and scattering fluxes of the quartz-sulfide deposit]. Izvestiya AN SSSR. Seriya: Geologiya, 1986, no. 2, pp.137-139.

2. Pogrebnyak Yu.F., Kondratenko L.A., Laperdina T.G. Rudnye elementy $v$ vodakh zony gipergeneza mestorozhdeniy Zabaykalya [Ore elements in the waters of the supergenesis zone of the Transbaikalia deposits]. Novosibirsk, Nauka Publ., 1989. 203 p.

3. Makarov V.N. Geokhimiya okruzhayushchey sredy Verkhneindigirskogo zolotonosnogo rayona [Geochemistry of the environment of the Verkhneindigirsky gold-bearing region]. Nauka $i$ obrazovaniye, 2008, no. 4, pp.45-48.

4. Plyusnin A.M., Dabaeva V.V. Redkozemelnye elementy v rudnichnykh i porovykh vodakh khvostokhranilishch Dzhidinskogo i
Bom-Gorkhonskogo GOKov [Rare earth elements in the mine and pore waters of the tailing dumps of the Dzhidinsky and BomGorkhonsky MPP]. XXII Soveshchaniye po podzemnym vodam Vostoka Rossii [XXII Meeting on groundwater in the East of Russia]. Novosibirsk, Novosibirsk State University Publ., 2018. pp. 384-388.

5. Dutova E.M. Geochemistry of fresh groundwater in the AltaiSayan folded area and adjacent areas of the West Siberian plate. Applied Geochemistry, 2020, vol. 120, pp. 104-119.

6. Dutova E.M., Nikitenkov A.N., Pokrovskiy V.D., Banks D., Frengstad B.S., Parnachev V.P. Modelling of the dissolution and reprecipitation of uranium under oxidising conditions in the zone of shallow groundwater circulation. Journal of Environmental Radioactivity, 2017, vol. 178-179, pp. 63-76.

7. Makarov V.N. Kriogennye geokhimicheskie oreoly rasseyaniya rudnykh komponentov [Cryogenic geochemical dispersion halos of ore components]. Nauka i tekhnika v Yakutii, 2010, no. 2, pp. 9-13. 
8. Gosudarstvenny doklad «O sostoyanii i ispolzovanii mineralnosyryevykh resursov Rossiyskoy Federatsii v 2016 i 2017 godakh» [The state report «On the state and use of mineral resources of the Russian Federation in 2016 and 2017»]. Ed. by E.A. Kiselev. Moscow, Mineral-Info Publ., 2018. 369 p.

9. Varenichev A.A., Komogortsev B.V., Gudzenko V.T. Osnovnye napravleniya zolotodobychi v Rossii [The main directions of gold mining in Russia]. Gorny informatsionno-analiticheskiy byulleten, 2017, no. 1, pp. 231-237.

10. Mikhailov B.K., Nekrasov A.I., Petrov O.V., Kimmelman S.A., Mikhailov S.B. Kontseptsiya novykh tsentrov ekonomicheskogo rosta v sovremennykh usloviyakh na primere Yano-Kolymskoy zolotorudnoy provintsii [The concept of new centers of economic growth in modern conditions on the example of the Yano-Kolyma gold ore province]. Regionalnaya geologiya i metallogeniya, 2010, no. 42 , pp. $58-65$.

11. Nekrasov A.I. Tipy geologo-strukturnykh obstanovok proyavleniya zoloto- i serebrorudnoy mineralizatsii v Yano-Kolymskoy i Zapadno-Verkhoyanskoy provintsiyakh, Severo-Vostok Yakutii [Types of geological and structural settings of occurrence of gold and silver ore mineralization in the Yano-Kolyma and WestVerkhoyansk provinces, North-East of Yakutia]. Rudy i metally, 2017, no. 1, pp. 5-18

12. Radomskaya V.I., Radomsky S.M., Kulik E.N., Rogulina L.I., Shumilova L.P., Pavlova L.M. Geokhimicheskaya spetsifika redkozemel'nykh elementov v poverkhnostnykh i podzemnykh vodakh polya Albynskogo zolotorudnogo mestorozhdeniya (Amurskaya oblast') [Geochemical specificity of rare earth elements in surface and ground waters of the field of the Albynskoe gold ore deposit (Amur region)]. Vodnyye resursy, 2016, vol. 43, no. 6, pp. 648-660.

13. Anisimova G.S., Protopopov R.I. Geologicheskoye stroyeniye sostav rud zoloto-kvartsevogo mestorozhdeniya Vyun, Vostochnaya Yakutiya [Geological structure and composition of ores of the Vyun gold-quartz deposit, Eastern Yakutia]. Rudy i metally, 2009, no. 5 , pp. 59-69.

14. Karta Rossii [Map of Russia]. 2015. Available at: https://www.freepng.ru/png-tfycud/ (accessed 10 December 2020).

15. Protopopov R.I., Suleimanov A.M., Pichugin E.P. Podschet zapasov zolotorudnogo mestorozhdeniya Vyun $v$ Verkhoyanskom uluse Respubliki Sakha (Yakutiya) po sostoyaniyu na 01.01.2009 [Calculation of the reserves of the Vyun gold deposit in the Verkhoyansk ulus of the Sakha Republic (Yakutia) as of 01.01.2009], in 3 books. Book 1. Yakutsk, 2009. $175 \mathrm{p}$

16. Kochurov B.I., Antipova A.V., Lobkovskiy V.A., Kostovska S.K. Ekologicheskaya situatsiya v Rossii na obzornoy karte [The ecological situation in Russia on the overview map]. Priroda, 2002, no. 12, pp. 51-56.

17. Yazikov E.G., Shatilov A.Yu. Geoekologicheskiy monitoring [Geoecological monitoring]. Tomsk, TPU Publ., 2003. 336 p.

18. Saet Yu.E., Revich B.A., Yanin E.P., Achkasov A.I., Basharkevich I.L., Onishchenko T.L., Pavlova L.N., Sarkisyan S.Sh., Smirnova R.S., Trefilova N.Ya. Geokhimiya okruzhayushchey sredy [Geochemistry of the environment]. Moscow, Nedra Publ., 1990. 335 p.

19. Vinogradov A.P. Vvedeniye v geokhimiyu okeana [An Introduction to Ocean Geochemistry]. Moscow, Nauka Publ., 1967. 215 p.

20. Shvartsev S.L. Obshchaya gidrogeologiya [General hydrogeology] Moscow, Nedra Publ., 1996. 324 p.

21. Ksenofontova M.I. The main hydrochemical parameters of surface waters of the upper reaches of the river Yana. Problems of regional ecology, 2018, no. 5. pp. 123-127. In Rus.

22. Savichev O.G. Investigation of the relationship between the chemical composition of waters and bottom sediments of Siberian rivers. Bulletin of the Tomsk Polytechnic University. Geo Assets Engineering, 2019, vol. 330, no. 5, pp. 178-188. In Rus.

23. Noble R.P., Gray D.J. Hydrogeochemistry for mineral exploration in Western Australia (I): Methods and equipment. Explore Newsletter, 2010, vol. 146, pp. 2-11.
24. Robertson I.D.M. Geochemical exploration around the Harmony gold deposit, Peak Hill, Western Australia. Geochemistry. Exploration, Environment, Analysis, 2001, vol. 4, pp. 113-127.

25. Ferreira da Silva E., Bobos I., Matos J.X., Patinha C., Reis A.P., Cardoso Fonseca E. Mineralogy and geochemistry of trace metals and REE in volcanic massive sulfide host rocks, stream sediments, stream waters and acid mine drainage from the Lousal mine area (Iberian Pyrite Belt, Portugal). Applied Geochemistry, 2009, vol. 24 (3), pp. 383-401.

26. Leybourne M.I., Johannesson K.H. Rare earth elements (REE) and yttrium in stream waters, stream sediments, and $\mathrm{Fe}-\mathrm{Mn}$ oxyhydroxides: fractio nation, speciation, and controls over REE + Y patterns in the surface environment. Geochimica et Cosmochimica Acta, 2008, vol. 72 (24), pp. 5962-5983.

27. Biddau R., Cidu R., Frau F. Rare earth elements in waters from the albitite-bearing granodiorites of Central Sardinia, Italy. Chemical Geology, 2002, vol. 182 (1), pp. 1-14.

28. Kharitonova N.A., Vakh E.A. Redkozemelnye elementy v poverkhnostnykh vodakh Amurskoy oblasti. Osobennosti nakopleniya i fraktsionirovaniya [Rare earth elements in the surface waters of the Amur region. Features of accumulation and fractionation]. Vestnik Tomskogo gosudarstvennogo universiteta, 2015, no. 396, pp. 232-244.

29. Shannon W.M., Wood S.A. The analysis of pictogram quantities of rare earth elements in natural waters. Rare earth elements in groundwater flow system, 2005, vol. 1, pp. 1-37.

30. Andersson K., Dahlqvist R., Turner D., Stolpe B., Larsson T., Ingri J., Andersson P. Colloidal rare earth elements in a boreal river: Changing sources and distributions during the spring flood. Geochimica et Cosmochimica Acta, 2006, vol. 70, pp. 3261-3274.

31. Bagard M.L., Chabaux F., Viers J., Stille P., Rihs S., Schmitt A., Dupre B. Seasonal variability of element fluxes in two Central Siberian rivers draining high latitude permafrost dominated areas. Geochimica et Cosmochimica Acta, 2011, vol. 75 (12), pp. 3335-3357.

32. Laukert G., Frank M., Bauch D., Hathorne E.C., Gutjahr M., Janout M., Hölemann J. Transport and transformation of riverine neodymium isotope and rare earth element signatures in high latitude estuaries: A case study from the Laptev Sea. Earth and Planetary Science Letters, 2017, vol. 477, pp. 205-217.

33. Viers J., Dupre B., Gaillardet J. Chemical composition of suspended sediments in World Rivers: new insights from a new database. Science of the Total Environment, 2009, vol. 407, pp. 853-868.

34. Martin J.M., Meybeek M. Elemental mass balance of material carried by world major rivers. Marine Chemistry, 1979, vol. 7 (3), pp. 173-206.

35. Duddy I.R. Redistribution and fractionation of the rare-earth and other elements in a weathering profile. Chemical Geology, 1980, vol. 30, pp. 363-381.

36. Ronnback P., Astroma M., Gustafsson J.P. Comparison of the behaviour of rare earth elements in surface waters, overburden groundwaters and bedrock groundwaters in two granitoidic settings, Eastern Sweden. Applied Geochemistry, 2008, vol. 23 (7), pp. $1862-1880$.

37. Davranche M., Pourret O., Gruau G., Dia A., Jin D., Gaertner D. Competitive binding of REE to humic acid and manganese oxide: Impact of reaction kinetics on development of cerium anomaly and REE adsorption. Chemical Geology, 2008, vol. 247 (1), pp. 154-170.

38. Meija J., Berglund M. Isotopic compositions of the elements 2013 (IUPAC Technical Report). Pure and Applied Chemistry, 2016, vol. 88 (3), pp. 293-306.

39. Platonova E.V., Kartashov A.V., Belyaev D.V., Karpychev A.V. Giperakkumulyatsiya tseziya ryaskoy LEMNA MINOR [Hyperaccumulation of cesium with duckweed LEMNA MINOR]. Izvestiya Samarskogo nauchnogo tsentra Rossiyskoy akademii nauk, 2019, vol. 21, no. 2, pp. 51-59. 


\section{Information about the authors}

Egor G. Yazikov, Dr. Sc., professor, National Research Tomsk Polytechnic University.

Andrey Yu. Mishankin, postgraduate student, National Research Tomsk Polytechnic University.

Nina A. Osipova, Cand. Sc., associated professor, National Research Tomsk Polytechnic University.

Ekaterina A. Filimonenko, Cand. Sc., associated professor, National Research Tomsk Polytechnic University.

Yuri A. Karpenko, postgraduate student, National Research Tomsk Polytechnic University.

Yuri P. Sobyanin, director, LLC Boguslavets. 